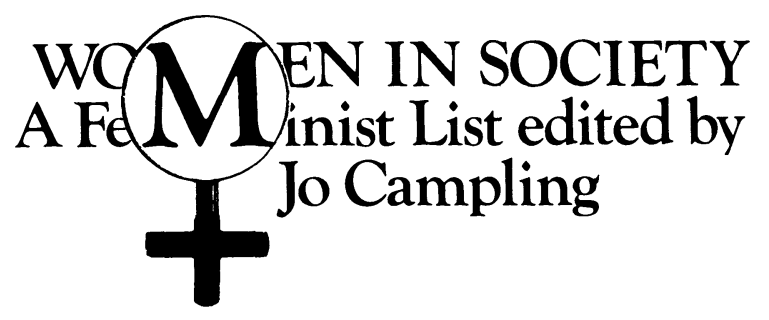

editorial advisory group

Maria Brenton, University College, Cardiff; Phillida Bunckle, Victoria University, Wellington, New Zealand; Miriam David, Polytechnic of the South Bank; Leonore Davidoff, University of Essex; Janet Finch, University of Lancaster; Jalna Hanmer, University of Bradford; Beverley Kingston, University of New South Wales, Australia; Hilary Land, University of Bristol; Diana Leonard, University of London Institute of Education; Susan Lonsdale, Polytechnic of the South Bank; Jean O'Barr, Duke University, North Carolina, USA; Arlene Tigar McLaren, Simon Fraser University, British Columbia, Canada; Jill Roe, Macquarie University, Australia; Hilary Rose, University of Bradford; Pat Thane, Goldsmiths' College, University of London; Jane Thompson, University of Southampton; Clare Ungerson, University of Kent at Canterbury; Judy Walkowitz, Rutgers University, New Jersey, USA.

The 1970s and 1980s have seen an explosion of publishing by, about and for women. This new list is designed to make a particular contribution to this process by commissioning and publishing books which consolidate and advance feminist research and debate in key areas in a form suitable for students, academics and researchers but also accessible to a broader general readership.

As far as possible books will adopt an international perspective incorporating comparative material from a range of countries where this is illuminating. Above all they will be interdisciplinary, aiming to put women's studies and feminist discussion firmly on the agenda in subject-areas as disparate as law, physical education, art and social policy. 


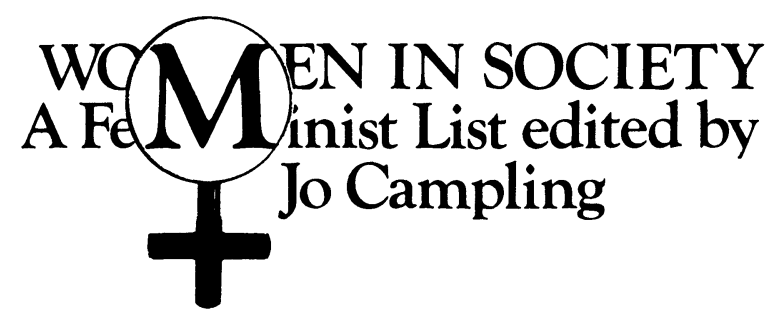

Published

Jenny Beale Women in Ireland: voices of change

Leonore Davidoff and Belinda Westover (editors) Our Work,

Our Lives, Our Words: women's history and women's work

Diana Gittins The Family in Question: changing households

and familiar ideologies

Frances Heidensohn Women and Crime

Muthoni Likimani (Introductory Essay by Jean O'Barr)

Passbook Number F.47927: women and Mau Mau in Kenya

Rosemary Ridd and Helen Callaway (editors) Caught Up in

Conflict: women's responses to political strife

Clare Ungerson (editor) Women and Social Policy: a reader

Forthcoming

Sheila Allen and Carol Wolkowitz Homeworking: myths and realities

Maria Brenton Women and Old Age

Sheila Button Women and Local Politics

Angela Coyle and Jane Skinner Women and Work: positive action for equal opportunities

Gillian Dalley Ideologies of Caring

Jennifer Hargreaves Women and Sport

Annie Hudson Troublesome Girls: adolescence, femininity

and the state

Ursula King Women and Spirituality

Susan Lonsdale Women and Disability

Sharon MacDonald, Pat Holden and Shirley Ardener Images of Women in Peace and War

Jan Pahl Marriage and Money

Lesley Rimmer Women's Family Lives

Deborah Valenze The Other Victorian Woman

Janet Wolff The Art of Women 


\section{Our Work, Our Lives, Our Words}

Women's History and Women's Work

Edited by

\section{Leonore Davidoff \\ and \\ Belinda Westover}

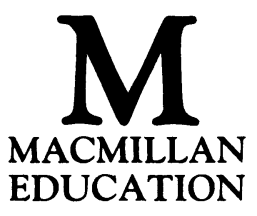


Selection and editorial matter (C) Leonore Davidoff and Belinda Westover 1986

Individual chapters (C) Leonore Davidoff, Belinda Westover, Eve Hostettler, Joanna Bornat, Frances Widdowson, Teresa Davy, Kay Sanderson, Elizabeth Crosthwait 1986

All rights reserved. No reproduction, copy or transmission of this publication may be made without written permission.

No paragraph of this publication may be reproduced, copied or transmitted save with written permission or in accordance with the provisions of the Copyright Act 1956 (as amended).

Any person whe does any unauthorised act in relation to this publication may be liable to criminal prosecution and civil claims for damages.

First published 1986

Published by

MACMILLAN EDUCATION LTD

Houndmills, Basingstoke, Hampshire RG21 2XS

and London

Companies and representatives

throughout the world

Photoset in Times by

CAS Typesetters, Southampton

British Library Cataloguing in Publication Data

Our work, our lives, our words: women's

history and women's work.-(Women in

society)

1. Women-Employment-Great Britain-

History

I. Davidoff, Leonore II. Westover, Belinda

III. Series

331.4 '0941 HD6135

ISBN 978-0-333-36599-1

DOI 10.1007 978-1-349-18376-0

\section{Series Standing Order}

If you would like to receive future titles in this series as they are published, you can make use of our standing order facility. To place a standing order please contact your bookseller or, in case of difficulty, write to us at the address below with your name and address and the name of the series. Please state with which title you wish to begin your standing order. (If you live outside the United Kingdom we may not have the rights for your area, in which case we will forward your order to the publisher concerned.)

Customer Services Department, Macmillan Distribution Ltd, Houndmills, Basingstoke, Hampshire, RG21 2XS, England. 
For Brenda Corti, whose warmth and enthusiasm has helped so many students and staff on the University of Essex social history programme over the years 


\section{Contents}

Preface $\quad$ ix

Notes on the Contributors xii

Acknowledgements $\quad$ xiv

1 'From Queen Victoria to the Jazz Age': Women's

World in England, 1880-1939

Leonore Davidoff and Belinda Westover

2 'Making do': Domestic Life among East Anglian

Labourers, 1890-1910

Eve Hostenier

3 'To Fill the Kids' Tummies': The Lives and Work of Colchester Tailoresses, 1880-1918

Belinda Westover

4 'What About That Lass of Yours Being in the Union?': Textile Workers and their Union in Yorkshire, 1888-1922

Joanna Bornat

5 'Educating Teacher': Women and Elementary

Teaching in London, 1900-1914

Frances Widdowson

6 'A Cissy Job for Men; A Nice Job for Girls': Women Shorthand Typists in London, 1900-1939 Teresa Davy 
viii Contents

7 'A Pension to Look Forward to . . .?': Women Civil Servant Clerks in London, 1925-1939

Kay Sanderson

8 'The Girl Behind the Man Behind the Gun': The Women's Army Auxiliary Corps, 1914-1918

Elizabeth Crosthwait

Further Reading

182

Index

186 


\section{Preface}

After the relative calm of mid-Victorian prosperity, England of the 1880 s was once again in turmoil. This rapid pace of change was to continue into the new century. The generations growing up between 1880 and 1914 were experiencing a merging of new and old, from industrial processes to the questioning of woman's place. The women whose lives form the substance of this book were born during these decades. Their lives should be taken as representative of millions of others who have left no personal records. For all of them, their formative years were touched in some way by the Great War. All lived through the experience of a divided nation in the inter-war years and their middle age was shadowed by yet another major war. While each was a unique individual, collectively they form the story of the lives of English women which links us with our own past. In this sense, each may be taken as a typical 'girl of the period'.

All the contributors to this volume have interviewed women born during those decades and oral evidence is an important linking theme of the chapters. Oral material is a valuable source for historians generally, but it is particularly important for the history of women's work and the family. In this field of study, documentary sources are often partial and inadequate. Not only is the experience of women filtered through the eyes of social commentators, most of who were men, but there are substantial gaps in the documentary evidence about what women were doing. Women's lives have been considered trivial and unchanging and thus unworthy of serious historical study, particularly in their domestic role. Therefore we know little about family life and about the distinct stages of women's life cycle. Even in the more public arena of the workplace, documentary sources tell us little or nothing about the actual work experience of women, the choices available to them or influences on their initial choice of occupation, for instance the mother's role in a girl's important first step into the wider world. Most importantly, 
oral history enables us to make the link between work and family life. Women do not experience their lives in compartments of home, work and leisure but mesh employment with domestic commitments. In this way their work fits around their lives, unlike the pattern regarded as normal because it applies to men. Finally, oral history does not simply tell the story of individual lives, it helps to tell the story of a generation and makes the link between people's life experiences and the wider historical context.

The contributors to this book are themselves the daughters and granddaughters of the generation of women whose experience forms its subject matter. Most of us are part of the ' 1945 generation' who benefited from the improvements in health, 'welfare and educational opportunities brought about by the post-war welfare state. All were University of Essex graduate students or staff who began their study as mature students. The majority were in their $30 \mathrm{~s}$ and 40s when the research upon which the contributions are based was carried out. Among themselves, the authors have fifteen children, and each has coped with the pressures of bringing up a family and caring for dependants while studying and working. In this respect our experience resembles that of the women we have interviewed and written about, and it is no accident that we chose to study women's history and women's work. Some of us have taught women's history in adult education and have often felt the need for a book like this which gives insights into women's everyday lives in the earlier part of our own century. Contrary to the opinion of many male historians, women's lives are varied and dynamic. Nevertheless, the lives of women in the generations before us, although very different from our own in many ways, have a similarity in that we too live within the constraints of a male-dominated society.

Leonore Davidoff and Belinda Westover describe the world into which these women were born; their education, the type of work available to them, living conditions, social life, patterns of birth, marriage and death. It discusses in some detail the typical nineteenth-century female occupation of domestic service. The following three chapters by Eve Hostettler, Belinda Westover and Joanna Bornat are concerned with working-class women. Work opportunities for them varied between monotony of long days in the textile mill, to the pick up and put down pattern of tailoring or the even more irregular harvest work in the spaces between cooking, cleaning and looking after children. 
Frances Widdowson, Teresa Davy and Kay Sanderson talked to women fortunate enough to have family backing and education, who took up the new white-collar positions becoming available. The education they received and the opening of such work to women were due, in part, to the efforts of late nineteenth-century feminists who understood the crucial importance of paid work as a basis for women's independence. All the contributions show, however, how difficult and at what cost to their families and themselves, was the effort to fit women's lives into the world of paid work. The anonymous structures of the factory or office were alien to many women's experience and they were almost always at a disadvantage compared with the male worker in terms of pay, working conditions and status. The final chapter, by Elizabeth Crosthwait, highlights these themes with the entry of women into the most masculine stronghold, the British army, during the First World War.

All the work in this volume originated in the Social History Programme of graduate research which has run since 1973 in the Sociology Department at the University of Essex: oral history and women's history have been special topics of study. We would like to thank those connected with the Programme: Brenda Corti, Judy Lown, Trevor Lummis and Paul Thompson, and the secretarial staff of the department, Carole Allington and Mary Girling. All real names of the women interviewed have been changed.

LEONORE DAVIDOFF BELINDA WESTOVER 


\section{Notes on the Contributors}

Joanna Bornat is an editor of the journal Oral History and worked for several years as educational director of a large national charity working for older people. She is Deputy Head of the ILEA Education Resource Unit for older people.

Elizabeth Crosthwait has worked for several years as a community worker in London.

Leonore Davidoff is a lecturer in social history in the Department of Sociology at the University of Essex. She teaches a graduate course in women's history and is the author of books and articles on domestic service, women and the family in nineteenth- and early twentieth-century Britain.

Teresa Davy qualified as a Careers Adviser in 1982 and worked for two years in schools in Hertfordshire. She works for the ILEA Careers Service in a south London Further Education college working with students who range from school-leavers to adults returning to education.

Eve Hostettler was born and brought up in Lincolnshire. She is employed on the Isle of Dogs in the heart of London's docklands, working with local residents on the recovery and preservation of their history.

Kay Sanderson is currently working on a research project at the University of East Anglia on the occupational and career differentiation of men and women and finishing her $\mathrm{PhD}$.

Belinda Westover is working as part-time lecturer in social history at the University of Essex and for the Open University and is an editor of the journal Life Stories. She has also taught in adult education, including women's studies courses. 
Notes on the Contributors xiii

Frances Widdowson works in the Equal Opportunities Department of the National Union of Teachers. This work covers equal opportunities for pupils in schools, career development for women teachers and the active involvement of women in the union. 


\section{Acknowledgements}

The author and publishers wish to thank the following who have kindly given permission for the use of copyright material:

The Controller of Her Majesty's Stationery Office for chart 'Economic Activity Rates for Married Females by Age 1921-1971' from Women and Work: A Statistical Survey.

International Labour Office for The War and Women's Employment: The Experience of the United Kingdom and the United States, Studies and Reports, New Series No. 1, Table 1, page 2, 'Numbers of Women Employed, July 1914-July 1918', C1946, ILO, Geneva.

Every effort has been made to trace all the copyright-holders, but if any have been inadvertently overlooked the publishers will be pleased to make the necessary arrangement at the first opportunity. 